\title{
Antifungal and antitumor models of bioactive protective peptides
}

\author{
ELAINE G. RODRIGUES ${ }^{1}$, ANDREY S. DOBROFF ${ }^{1}$, CARLOS P. TABORDA ${ }^{2}$ and LUIZ R. TRAVASSOS ${ }^{1}$ \\ ${ }^{1}$ Unidade de Oncologia Experimental, Departamento de Microbiologia, Imunologia e Parasitologia, Universidade Federal de São Paulo \\ Rua Botucatu, 862, $8^{\circ}$ andar, 04023-062 São Paulo, SP, Brasil \\ ${ }^{2}$ Departamento de Microbiologia, Instituto de Ciências Biomédicas, Universidade de São Paulo \\ Av. Prof. Lineu Prestes 1374, Cidade Universitária, 05508-900 São Paulo, SP, Brasil \\ Manuscript received on June 27, 2008; accepted for publication on March 31, 2009; \\ contributed by LUIZ R. TRAVASSOS*
}

\begin{abstract}
Peptides are remarkably reactive molecules produced by a great variety of species and able to display a number of functions in uni- and multicellular organisms as mediators, agonists and regulating substances. Some of them exert cytotoxic effects on cells other than those that produced them, and may have a role in controlling subpopulations and protecting certain species or cell types. Presently, we focus on antifungal and antitumor peptides and discuss a few models in which specific sequences and structures exerted direct inhibitory effects or stimulated a protective immune response. The killer peptide, deduced from an antiidiotypic antibody, with several antimicrobial activities and other Ig-derived peptides with cytotoxic activities including antitumor effects, are models studied in vitro and in vivo. Peptide 10 from gp43 of P. brasiliensis (P10) and the vaccine perspective against paracoccidioidomycosis is another topic illustrating the protective effect in vivo against a pathogenic fungus. The cationic antimicrobial peptides with antitumor activities are mostly reviewed here. Local treatment of murine melanoma by the peptide gomesin is another model studied at the Experimental Oncology Unit of UNIFESP.
\end{abstract}

Key words: bioactive peptides, Paracoccidioides brasiliensis, tumor cells, killer peptide, melanoma, apoptosis.

\section{INTRODUCTION}

Bioactive peptides arise from proteins by the action of peptidases or are chemically synthesized based on certain templates of natural sequences that have been selected by a variety of screening methods. Peptides can be designed aiming at enhanced functional activity by using amino acid substitutions and chemical modification. Owing to their great diversity of binding properties, peptides can play roles of biochemical reagents, pharmacological drugs, hormones, antibiotics, vaccines and mediators of neural and immunological signaling. Peptides interact with membrane structures, are specifically

In commemoration of the $75^{\text {th }}$ anniversary of Escola Paulista de Medicina/Universidade Federal de São Paulo.

*Member Academia Brasileira de Ciências

Correspondence to: Dr. Luiz R. Travassos

E-mail: travassos@unifesp.br recognized by cell surface receptors or act as ligands interacting with intracellular compounds and subcellular structures. Peptides can include epitopes recognized by antibodies and TCRs, and those called protective epitopes elicit a protective immune response. On focusing the actual fungal and tumor models, peptides that display direct cytotoxicity on target cells or elicit a protective immune response in animals experimentally infected or challenged with tumor cells have been investigated.

\section{ANTIFUNGAL PEPTIDES}

During the past decades, an increase in the incidence of fungal diseases has been recognized mainly caused by Candida spp. and filamentous fungi such as Aspergillus spp. (reviewed in Mavor et al. 2005 and Brakhage 2005). To date, there are no licensed fungal vaccines, and 
the use of antimycotics is the only option for the treatment of fungal infections. Currently used antimycotics, however, frequently have a limited activity spectrum, are available only in intravenous formulations, favor resistance development, and cause serious side-effects (reviewed in François et al. 2005). Thus, the search for new antifungal therapies is strongly stimulated, and the use of antifungal peptides is a promising alternative.

Antifungal properties of peptides have been reviewed by De Lucca and Walsh (2000). There are 405 peptides with antifungal properties described, comprising linear or cyclic, hydrophobic or amphipathic structures (http://aps.unmc.edu/AP/main.php).

Their cytotoxicity may involve binding to and disruption of the membrane (Shai 1995), membrane penetration and interaction with the mitochondria (Helmerhorst et al. 1999) or pore formation (Bechinger 1997). Antifungal peptides have been studied in bacteria, fungi, plants, insects, amphibians and mammals. Relevant examples are given next.

Syringomycins, syringostatins and syringotoxins from Pseudomonas syringae are lipodepsipeptides highly lethal to Candida albicans, Aspergillus and $\mathrm{Fu}$ sarium species (De Lucca and Walsh 2000, De Lucca et al. 1999, Sorensen et al. 1996). Glycopeptide cepacidines from Burkholderia cepacia are active against Candida sp., Aspergillus niger, Fusarium oxysporum and Cryptococcus neoformans (Lee et al. 1994, Lim et al. 1994). Antifungal peptidylnucleoside nikkomycins are produced by Streptomyces tendae, act by inhibiting chitin biosynthesis and were effective in murine infections by Coccidioides immitis and Blastomyces dermatitidis (Hector et al. 1990). Zeamatin, the 22 kilodalton $(\mathrm{kDa})$ peptide produced by Zea mays, permeabilizes the fungal membrane and kills $C$. albicans with a minimal inhibitory concentration (MIC) of $0.5 \mu \mathrm{g} / \mathrm{ml}$ (Roberts and Selitrennikoff 1991). Cecropins from the silk moth Hyalopora cecropia are linear, lytic peptides effective against germinating conidia of $F$. oxysporum and A. fumigatus (De Lucca et al. 1998). Both the Land D-isomeric forms of cecropin B were fungicidal (De Lucca et al. 2000). Drosomycin is a 44 amino acids (aa) inducible peptide active against $F$. oxysporum (Lemaitre et al. 1997). There is no evidence of adaptive protein evolution in the drosomycin genes, suggesting that they do not coevolve with pathogens (Jiggins and Kim 2005). In contrast, antimicrobial peptides (AMPs) appear to undergo a rapid adaptive evolution in vertebrates. In frogs, each species produces 10-20 AMPs that differ in size, sequence and specificity, and this rapid diversification is driven by evolutionary selection (Duda et al. 2002). Dermaseptins, produced by Phyllomedusa sauvagii, a South American frog, are lysine-rich linear peptides fungicidal for A. flavus, A. fumigatus and F. oxysporum (Mor et al. 1994). Magainins are antifungal peptides produced by the African frog Xenopus laevis (De Lucca and Walsh 2000). They are not hemolytic and inhibit Candida albicans (Zasloff 1987). Plant [DmAMP1 from dahlia (Dahlia merckii), RsAFP2 from radish (Raphanus sativus), HsAFP1 from coral bells (Heuchera sanguinea), Psd1 from pea (Pisum sativum), MsDef1 from alfalfa (Medicago sativa) and MtDef2 from barrel medic (Medicago truncatula)], insects (Termicin from the termite Pseudacanthotermes spiniger, Drosomycin from the fruitfly Drosophila melanogaster, Heliomicin from the tobacco budworm Heliothis virescens $)$ and human $[\beta-$ defensin 1 (HBD1), $\beta$-defensin 2 (HBD2), $\beta$-defensin 3 (HBD3)] defensins showed antifungal properties (reviewed in Aerts et al. 2008). Although there are no clear similarities in the mode of action of these defensins, the presence of sphingolipid glucosyl ceramide (GlcCer) in fungal membranes seems to play a central role in the action of some defensins (Thevissen et al. 2004). Only Psd1 was internalized in the fungal cell, affecting the normal progression of the cell cycle (Lobo et al. 2007), and it is possible that the other defensins stay outside the cell inducing fungal cell death after interaction with their target (e.g. sphingolipids) and modulation of intracellular signaling cascades (Aerts et al. 2008). RsAFP2 was also effective in an in vivo prophylactic model of murine candidiasis (Tavares et al. 2008).

$\beta$-Defensins include porcine cationic, cysteine-rich protegrins which inhibited C. albicans (Cho et al. 1998). Gomesin, a cationic AMP isolated from the hemocytes of the unchallenged Brazilian spider Acanthoscurria gomesiana (Silva et al. 2000), is structurally related to protegrins and exerts microbicidal activity against filamentous fungi, yeast and parasites. Gomesin bound to the surface of Cryptococcus neoformans, resulting in cell death by membrane permeabilization. Fungal growth, in 
the presence of the peptide, induced a decrease in capsule expression, rendering cells more susceptible to brain phagocytes and, in association with fluconazole, in concentrations with low antimicrobial activity $(0.1-1 \mu \mathrm{M})$, inhibited fungal growth and enhanced the antimicrobial activity of brain phagocytes (Barbosa et al. 2007). One of the models described in the present review is that of gomesin cytotoxicity in murine and human tumor cells (Rodrigues et al. 2008).

Among the antifungal peptides produced by fungi, the echinocandins interfere with the cell wall biosynthesis (Denning 1997) and the pneumocandins, aculeacins, WF11899, and mulundocandins have a modified echinocandin B peptide core (Debono and Gordee 1994, Kurtz and Douglas 1997). Echinocandins are produced by Aspergillus nidulans and A. rugulosus and are effective against Candida $(\mathrm{MIC}=0.6 \mu \mathrm{g} / \mathrm{ml}$ for echinocandin B and C. albicans) (reviewed in De Lucca and Walsh 2000). Clinical trials have started with molecules of the echinocandin group, VER-002, FK463 and caspofungin (MK-0991) modified for increased solubility and active against Candida spp. and Aspergillus spp. Vechinocandin and FK463 were effective in the treatment of esophageal candidiasis, the latter in AIDs patients (reviewed in De Lucca and Walsh 2000). Clinical trials with caspofungin (derived from pneumocandin), a drug that inhibits $\beta-1,3 \mathrm{D}$-glucan synthase, have shown excellent results in the treatment of Candida infections and invasive aspergillosis refractory to other antifungal agents (i.e., conventional or lipid formulations of amphotericin B and/or itraconazole). Aureobasidins are produced by Aureobasidium pullulans, interfere with sphingolipid synthesis and are effective against murine candidiasis (Nageic et al. 1997, Takesako et al. 1993).

\section{KILLER TOXINS AND KILLER PEPTIDES}

Killer yeasts secrete killer toxins that target susceptible cells in a two-step receptor-mediated manner. They bind to cell wall receptors and translocate to the plasma membrane. They can then interact with secondary receptors or enter susceptible cells to exert a cytocidal effect (Magliani et al. 1997, Schmitt and Breinig 2006). $\quad \beta-1,6$ Glucan, $\alpha-1,3$ mannoprotein and $\beta-1,3$ glucan are possible receptors, the latter for killer toxins from species of Pichia and Williopsis. Killer toxins kill susceptible cells by various mechanisms, including the induction of cation-selective ion channels in the plasma membrane, interference in the cell cycle (G1, G1/S, S arrest), chromosomal DNA synthesis and anticodon nuclease (Schmitt and Breinig 2006, Santos and Marquina 2004, Jablonowski and Schaffrath 2007, Klassen et al. 2004). Killer toxins can induce apoptosis mediated by yeast caspase Ycalp, characterized by DNA fragmentation, and phosphatidylserine external membrane expression. This could be a general cell death mechanism under natural environmental conditions (Paluszynski et al. 2007, Schmitt and Reiter 2008).

The direct use of killer toxins in antifungal therapy was discouraged owing to some of their properties. They are generally heat-labile, protease-sensitive and act within a narrow $\mathrm{pH}$ and temperature range. They are antigenic and toxic, as shown for Pichia anomala killer toxin (Pettoello-Mantovani et al. 1995). To overcome these pitfalls of a potential therapeutic agent, immunological derivatives were generated on the basis of the idiotypic network that mimicked the toxic effect of P. anomala killer toxin (Polonelli et al. 1991). Killer antibodies with the internal image of the active site of a killer toxin, which acted as antibiotics, were then obtained. They exerted significant therapeutic effects in experimental models of candidiasis, aspergillosis and pneumocystosis.

Toxic effects were also obtained with single chain variable fragment ( $\mathrm{scFv}$ ) preparations and they were further examined by synthesizing overlapping decapeptides which correspond to the light chain of antibodies $\left(\mathrm{V}_{\mathrm{L}}\right)$ and heavy chain of antibodies $\left(\mathrm{V}_{\mathrm{H}}\right)$ regions. These regions include the complementary determining regions (CDRs) that were tested in vitro against $C$. albicans. Several peptides were active and one of them, corresponding to the framework sequence with the final three amino acids belonging to $V_{L} C D R 1$, was selected. It was very cytotoxic and the substitution of the N-terminal glutamic acid by alanine generated a peptide with the AKVTMTCSAS sequence that was several times more active and was called killer peptide (KP). The KP interacted with $\beta$-glucan and this binding was inhibited in a dose dependent manner by laminarin (Polonelli et al. 2003). The peptide was as active as the killer antibody against a number of microbial pathogens in ad- 
dition to C. albicans, and was effective even in normal and immunocompromised animals against vaginal and systemic candidiasis (Polonelli et al. 2003), disseminated cryptococcosis (Cenci et al. 2004) and paracoccidioidomycosis (Travassos et al. 2004a). The KP is very stable forming dimers in non-reducing conditions without loss of activity (Magliani et al. 2004a, b).

The remarkable cytotoxicity of KP was also examined by electron microscopy. C. albicans cells treated with KP showed important internal alterations, including cell wall swelling with middle electron-dense region, collapse of the plasma membrane, condensation and fragmentation of nuclear material, and alteration of mitochondria structure (Fig. 1A). In a dividing cell with a big vacuole and chromatin condensation and fragmentation, cellular alterations were seen beyond the septum separating both cells, with the daughter cell already affected by the KP showing an altered cell wall (Fig. 1B).

\section{A MODEL OF DIRECT ANTIFUNGAL EFFECT OF A PEPTIDE}

Glucans, chitin and mannoproteins, in addition to plasma membrane sterols, are natural targets of antifungal drugs. Additional targets are ceramide monohexosides, ubiquitously present on the fungal cell wall and displaying several roles in fungal cells (Nimrichter et al. 2008). In C. neoformans (Rodrigues et al. 2000), C. albicans and Pseudallescheria boydii, these glycolipids were identified as targets of human antibodies that inhibited fungal growth. Other targets are melanin, adhesion factors, and cell wall enzymes. The killer decapeptide (KP) described above was synthesized and engineered demonstrating a strong candidacidal activity in vitro and curing rat vaginal infections caused by fluconazole-susceptible and -resistant C. albicans strains (Polonelli et al. 2003). The fungicidal activity of KP in vitro against $P$. brasiliensis and its therapeutic activity in vivo have been reported (Travassos et al. 2004a).

Paracoccidioidomycosis (PCM) is the prevalent systemic mycosis in South America with most reported cases in Brazil. It is a major cause of disability and death among young adult rural workers. Sequels are frequent. The evolution of the disease and the mortality burden are influenced by the socio-economic status of the patients. Although long periods of antifungal ther-
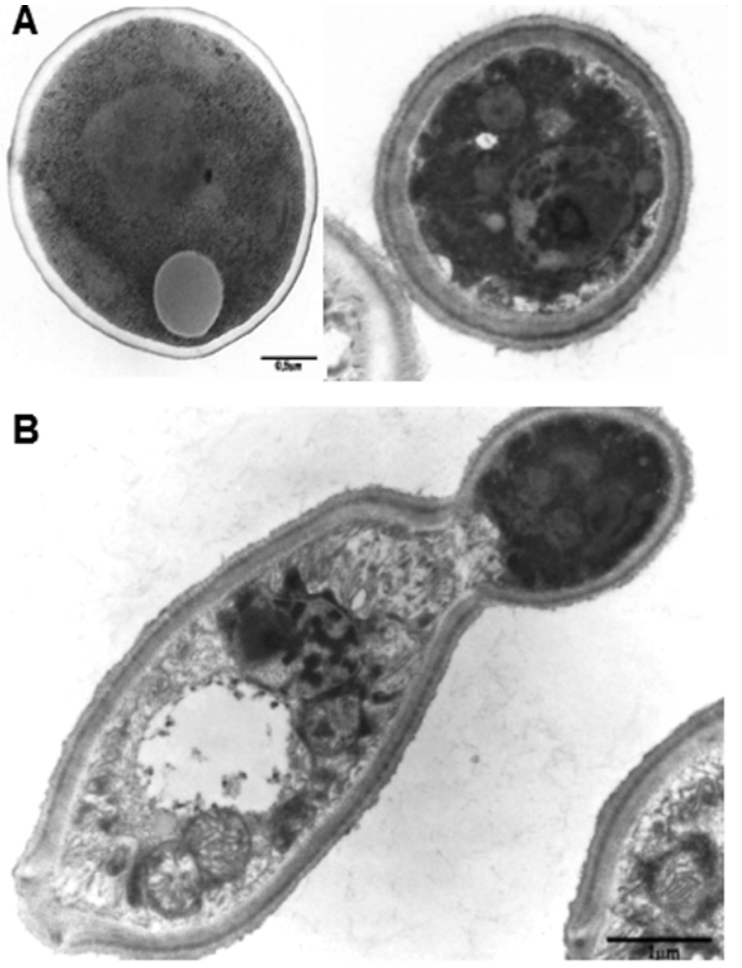

Fig. 1 - Electron micrographs showing the cytotoxic effects of the killer peptide (KP) on Candida albicans. (A) Normal untreated or treated with the inactive scrambled peptide $C$. albicans yeast cell (left) as compared with the KP-treated yeast cell (right). Major alterations can be seen as the swelling of the cell wall, plasma membrane collapse, chromatin condensation and nuclear fragmentation. (B) An elongated C. albicans cell with a budding cell, both affected by KP treatment. The same alterations as in (A) are seen with nuclear fragmentation and cytoplasmic blebs invading the daughter cells beyond the septum.

apy with itraconazole, amphotericin or sulfamethoxazole/trimethoprim are used in clinical practice, relapses are a significant unsolved problem (Travassos et al. 2008b). Vaccination against PCM is now a prospective goal after P10, and four other peptides derived from the major diagnostic antigen gp 43 were found to be promiscuously presented by several human leukocyte antigens DR, MHC class II molecules (HLA-DR) (Iwai et al. 2003). Such a vaccine could function as an adjuvant to chemotherapy significantly reducing the time of treatment (Travassos et al. 2008a, b).

Wide-spectrum antimicrobial peptides, such as KP, might also be considered as an alternative adjuvant to chemotherapy, and the projected peptide immunotherapy to shorten the time of treatment and as another op- 
tion in cases of anergy and drug resistance. Multiplybudding yeast cells of $P$. brasiliensis had their viability hampered at $39 \mathrm{ng}$ of KP/yeast in distilled water. The D-isomeric form of KP was also active. Further, the decapeptide was therapeutic in $\mathrm{B} 10 \mathrm{~A}$ mice infected intravenously with $3 \times 10^{6}$ cells of $P$. brasiliensis $\mathrm{Pb} 18$ isolate administered intraperitoneally at $3.3 \mu \mathrm{g} / \mathrm{g}$ of body weight, $1 \mathrm{~h}$ after infection and 1 and 2 days later. With this protocol, no colony forming units (CFUs) were obtained from lung, spleen and liver after 8 days of fungal challenge in the KP treated animals. In these animals compared to those injected with the scrambled peptide, the liver granulomas were smaller and fewer with no visible fungi. The lungs were less infiltrated with extensive areas of normal alveoli and no visible fungi. Spleens also were little affected, with no detectable fungi.

It was clear therefore that KP was an effective inhibitor of $P$. brasiliensis in vitro and in vivo (Travassos et al. 2004a).

It is still not clear whether $\alpha-1,3$ glucan, the predominant polysaccharide of yeast forms of $P$. brasiliensis, is a target of KP. There is, however, evidence that yeast forms may have $\beta$-glucans at the cell surface. Macrophages from pentraxin 3 transgenic (PTX3 $\mathrm{Tg}$ ) mice showed improved opsonin-independent phagocytosis of zymosan particles and yeast forms of $P$. brasiliensis. In the case of $P$. brasiliensis, an enhanced microbicidal activity accompanied by high production of nitric oxide was observed in macrophages from transgenic mice. Blockade of dectin-1 receptor for $\beta-1,3$ glucan inhibited the phagocytosis of zymosan particles by PTX3 Tg macrophages, pointing out the relevant role of dectin-1 as the main receptor involved in zymosan and possibly also of $P$. brasiliensis uptake (Diniz et al. 2004).

\section{BIOACTIVE PEPTIDES EXPRESSED AS IMMUNOGLOBULIN ISOLATED CDRS}

The discovery by Polonelli et al. (Polonelli et al. 2003, Magliani et al. 2004a, b) that internal sequences of immunoglobulin variable regions may display antibiotic properties prompted us to investigate the activity of monoclonal antibody (mAb) CDRs tested as synthetic peptides. Immunoglobulins have polymorphic heavy and light chains and the idiotypic variability is related to the diversity of the antigen binding site and particularly to the hypervariable domains called complementaritydetermining regions (CDRs). There are 6 CDRs in both variable regions of light $\left(\mathrm{V}_{\mathrm{L}}\right)$ and heavy chains $\left(\mathrm{V}_{\mathrm{H}}\right)$ with background variability on each side of the CDRs. The CDRs are named H1, H2, H3 and L1, L2, L3 in heavy and light chains, respectively. The framework sequences between CDRs can be similar or identical. Although all CDRs are expected to contribute to antigen binding with variable affinity, only the CDR 3 from $\mathrm{V}_{\mathrm{H}}$ when tested as an isolated linear or cyclic peptide was found to have the same specificity of the original antibody, sharing some of its biological properties. $\mathrm{V}_{\mathrm{H}}$ CDR3 (H3) peptides with such properties have thus been called micro (mini) antibodies (Levi et al. 1993, Bourgeois et al. 1998). They can even compete with the antibody for binding to a certain antigen. The other CDRs generally do not show a similar reactivity when tested as isolated peptides.

Recently we showed, in collaboration with Polonelli's and Ponton's groups from Parma and Bilbao, respectively, that, independently of the specificity of the native $\mathrm{Ab}, \mathrm{CDRs}$ other than $\mathrm{H} 3$ may display, with high frequency, antimicrobial, antiviral and antitumor activities in a way reminiscent of molecules of early innate immunity (Litman et al. 2005). The following mAbs

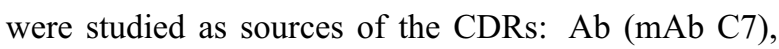
raised against a $C$. albicans antigen; mouse $\mathrm{mAb}$ pc42, sharing $\mathrm{H} 1$ and $\mathrm{H} 2$ with $\mathrm{mAb} \mathrm{C} 7$; and human $\mathrm{mAb}$ $\mathrm{HuA}$, sharing no CDR either with $\mathrm{mAb} C 7$ or $\mathrm{mAb} p c 42$, with specificity for difucosylated blood group A. All mAbs generated CDRs that, represented by synthetic peptides, showed in vitro, ex vivo and/or in vivo differential antimicrobial (C. albicans), antiviral (HIV-1) and/or antitumor activities (Polonelli et al. 2008).

CDRs C7/pc42 H2 and HuA L1 were directly cytotoxic for melanoma and HL-60 (human leukemia) cells causing caspase-dependent apoptosis. H2 peptide activity was receptor-mediated in melanoma cells. Both C7 $\mathrm{H} 2$ and HuA L1 peptides in the C-terminal amidated form were active against lung colonization by melanoma cells by intravenous injection (i.v.). Peptides were administered by intraperitonial injection (i.p.) $(250 \mu \mathrm{g})$ every other day for 11 days, starting on the 1st day after tumor cell challenge. After 22 days and compared to the untreated control, the number of cancerous nod- 
ules in the lungs of peptide treated animals were very few. Presumably, even better results could have been obtained by optimization of the peptide administration protocol (Polonelli et al. 2008). C7 H3 but not C7/pc42 $\mathrm{H} 2$ competed with $\mathrm{mAb} \mathrm{C} 7$ for binding to phosphatidylcholine, the probable ligand of polyreactive $\mathrm{C} 7(\mathrm{IgM})$ on melanoma cells. This CDR (C7 H3) together with the H3 CDRs of two anti-melanoma mAbs (A4 and A4M), that competed with the antibodies for binding to melanoma cells, were three examples of micro (mini) antibodies shown in our laboratory (unpublished results).

\section{A PEPTIDE VACCINE AGAINST PARACOCCIDIOIDOMYCOSIS}

The main diagnostic antigen of $P$. brasiliensis was identified in our laboratory in 1986 (Puccia et al. 1986; reviewed Travassos et al. 2004b). Glycoprotein gp43 reacts with $100 \%$ sera of patients with paracoccidioidomycosis from a vast region of South America, with the possible exception of sera from certain Western areas. It elicits an immune response that protects against the intratracheal challenge by virulent $P$. brasiliensis yeast cells. This molecule has been cloned and sequenced (Cisalpino et al. 1996). Apart from B cell epitopes, which are beginning to be identified, the gp43 carries an immunodominant epitope that elicits a predominant IFN- $\gamma$-mediated Th- 1 response. It is responsible for delayed type sensitive (DTH) reactions in infected animals (Rodrigues and Travassos 1994). The T-CD4+ cell epitope was mapped to a peptide called P10 with the QTLIAIHTLAIRYAN sequence, the HTLAIR hexapeptide core being essential for priming the immune response (Taborda et al. 1998). P10 was as protective as the gp43 in intratracheal injection (i.t.) challenged mice, being administered i.p with complete Freund's adjuvant (CFA). The nucleotide sequence encoding P10 was conserved in a number of isolates (Travassos et al. 2004b).

The $\mathrm{T}$ cell epitope in peptide $\mathrm{P} 10$ is presented by major histocompatibility complex (MHC) class II molecules from three different mouse haplotypes (Taborda et al. 1998). Promiscuity of $P 10$ was also observed with different HLA-DR alleles, as this peptide and a derivative (gp43 ${ }^{180-194}$ ) without the C-terminal asparagine residue and with $\mathrm{N}$-terminal lysine bound to nine prevalent
Caucasian HLA-DR molecules (Iwai et al. 2003). Additional gp43 peptides were also identified using the TEPITOPE algorithm, which bound promiscuously to several HLA-DR molecules. As pointed out before (Travassos et al. 2008a, b) this is an essential property of a vaccine peptide candidate considering the genetic diversity of the target immunizable population.

In 29 patients with PCM and submitted to chemotherapy, $79 \%$ of them recognized one peptide selected by the TEPITOPE algorithm. By pooling peptides gp $43^{45-59}$, gp $43^{106-120}$, gp $43^{181-195}$ or P10, and gp43 $283-298$, the recognition frequency increased to $86 \%$ (Iwai et al. 2007). Overall for 25 Caucasian HLA-DRs, P10 and neighboring peptides were predicted to bind (TEPITOPE) to $90 \%$ or more of these molecules. Very few healthy individuals had peripheral blood mononuclear cells (PBMC) proliferating with gp43 and even fewer with gp43 derived peptides. They may have been exposed to $P$. brasiliensis on a trip to reserve areas of the fungus or cross-reacted with related fungal antigens, possibly also exo- $\beta$-1,3-D-glucanases. Site homologous but unidentical sequences, in comparison with P10, were found in $\beta$-1,3-glucanases from Aspergillus nidulans, Histoplasma capsulatum, Blastomyces dermatitidis and Lacazia loboi (a gp43-like protein).

The rationale for a peptide vaccine based on P10 has been discussed recently (Travassos et al. 2008a). Basically: "Stimulation of an effective IFN- $\gamma$-producing T-helper response can simultaneously trigger the production of potentially protective antibodies and the activation of $\mathrm{CD} 8^{+} \mathrm{T}$ cells in addition to activation of phagocytic cells. In the presence of several immunogenic molecules of the fungal agent, stimulation of one arm of the immune system may alter a state of early or installed immunosuppression". Since treatment of fungal infections and particularly of PCM involves chemotherapeutic drugs, a peptide vaccine could work as an adjuvant to reduce the treatment period, which is usually long, avoid relapses and reverse the potentially lethal anergic cases. It also could help to treat those cases of fungal drug resistance.

To tackle the above issues while using experimental $\mathrm{PCM}$ in Balb/c mice, P10 immunization was associated with chemotherapy in i.t. infected animals using two protocols. In the first protocol, infected mice were treated 
with P10 and/or a chemotherapeutic drug starting after $48 \mathrm{~h}$ of infection. In the second protocol, P10 and/or drug treatment was started after 30 days of infection. It aimed at reproducing a condition of established infection as in patients with PCM. The treatment was held for 30 days, during which groups of mice received i.p. doses of itraconazole, fluconazole, ketoconazole, sulfamethoxazole or trimethoprim-sulfamethoxazole at every $24 \mathrm{~h}$. Amphotericin B was given at every $48 \mathrm{~h}$. P10 was administered weekly for 4 weeks, initially in CFA and three times in incomplete Freund's adjuvant (Marques et al. 2006).

In all cases, there was an additive protective effect with the combination of P10 immunization and chemotherapy. Animals treated with sulfamethoxazole showed early protection followed by relapse. Significantly, the association of sulfamethoxazole and P10 successfully controlled the infection. In the second protocol, the fungal burden was examined after 60 and 120 days of infection. An additive protective effect of P10 immunization and drug treatment was also observed, with 60 to $80 \%$ reduction in lung CFUs. Chemotherapy alone induced a predominant Th-2 response with increased production of IL-4 and IL-10 detected in lung homogenates, whereas $\mathrm{P} 10$ vaccination stimulated a Th1 response, rich in IFN- $\gamma$ and IL-12 without suppressing the Th-2 response (Marques et al. 2006). These are encouraging results in short term experiments. It is probable that an increased protective effect will be obtained in long term trials in which the animals will have time to completely recover of the fungal infection.

The condition of anergy was addressed as follows. Balb/c mice were treated with dexamethasone-21 phosphate added to drinking water. Negative DTH with $P$. brasiliensis antigen was obtained after 30 days. Immunosuppressed mice $(\mathrm{n}=10)$, infected with virulent $P$. brasiliensis, began to die 10 days after infection, and all animals were dead after 70 days. Chemotherapy and/or P10 immunization of immunosuppressed animals was started 15 days after i.t. infection and all treated animals survived thereafter. Chemotherapy and P10 immunization conferred additive protection. A significant increase in IL-12 and IFN- $\gamma$ and decrease of IL-4 and IL-10 were observed in mice immunized with P10 alone or associated with antifungal drugs (Marques et al. 2008). These results suggest that $\mathrm{P} 10$ immunization can be protective in anergic patients.

Delivery of peptides for an efficient immunization has always been a concern of our group because previous experiments have always used CFA as an adjuvant. The following alternatives therefore have been investigated.

Early studies have shown that immunization of $\mathrm{Balb} / \mathrm{c}$ mice with a mammalian expression vector (VRgp43) carrying the full gene of gp43 with Cytomegalovirus (CMV) promoter induced $\mathrm{B}$ and $\mathrm{T}$ cell-mediated immune responses which were protective against the i.t. challenge by virulent $P$. brasiliensis yeast forms (Pinto et al. 2000). The cellular immune response in mice immunized with VR-gp43 was kept for at least 6 months after immunization. A similar construction with P10 was made several years later. Immunization with the P10 minigene in plasmid DNA alone or associated with a plasmid carrying mIL-12 insert was tested in Balb/c mice i.t. infected with a virulent isolate $(\mathrm{Pb} 18)$ of $P$. brasiliensis. A significant reduction of fungal burden in lung, spleen and liver was obtained with production of IL-12 and IFN- $\gamma$ and reduction of IL-4 levels in lung homogenates (G. Rittner et al., unpublished results).

The construction of MAP (multiple antigen peptide) was also tried to deliver a tetravalent antigen containing P10 sequence. MAP-10, or M10, had four equal LIAIHTLAIRYAN (QT-less P10) chains synthesized on a branched lysine core. Lymph node cell proliferation from P10 or M10-sensitized mice was identical with in vitro stimulation with either P10 or M10. Immunization with single dose of M10 without adjuvant was protective with few lung, spleen and liver CFUs and few or no yeasts in lung histopathological sections (Taborda et al. 2006).

In Balb/c mice infected i.t. for 30 days, the protective effect of P10 was tested alone or mixed with adjuvants: alum, monophosphoryl lipid A or complete Freund's adjuvant (Travassos et al. 2008a, b). Unexpectedly, P10 administered in phosphate-buffered saline was most effective with a significant reduction in lung CFUs with no fungi detected in spleens and livers.

The protective effect of P10 has also been tested with anti-gp43 mAbs. Anti-gp70 mAbs have been described as protective against experimental PCM (Mattos Grosso et al. 2003). In patients that underwent chemo- 
therapy, both gp 43 and gp70 are markers for monitoring successive treatment and cure through their decreased antigenemia and specific antibody response (Marques da Silva et al. 2004, Silva et al. 2004). In the experimental Balb/c model of PCM infection, anti-gp43 mAb $3 \mathrm{E}$ effectively reduced the fungal burden and promoted phagocytosis in vitro (Buissa-Filho et al. 2008). The recognized epitope in the gp43 was mapped to the sequence NHVRIPIGYWAV shared with Aspergillus fumigatus, A. oryzae and B. graminis internal sequences of $\beta$-1,3-glucanases. This peptide could increase the protective effect of $\mathrm{P} 10$ in a possible peptide vaccine against PCM.

Again, as stressed, we quote our own thought expressed before (Travassos et al. 2008a): "Short term protocols (30 to 45 days) have the advantage of allowing repeated experiments to define a certain response. However, longer periods of treatment and observation may lead to even more effective results, aiming at sterilization in experimental models with massive infection loads".

\section{ANTITUMOR PEPTIDES}

Cancer remains as a major source of mortality and morbidity around the world, despite numerous recent advances in treatment alternatives. Chemotherapy and, more recently, biochemotherapy, is still the choice treatment for advanced and metastatic disease (Espinosa et al. 2003). It is, though, often associated with deleterious side effects caused by drug-induced damage to healthy cells and tissues (Buzaid and Atkins 2001). Quiescent or slowly proliferating cancer cells are refractory to the cytotoxic effect of drugs interfering with DNA synthesis (Naumov et al. 2003) and, frequently, cellular changes affected sensitivity to chemotherapeutic drugs by increased expression of drug-detoxifying enzymes and/or drug transporters, altered interactions between the drug and its target, increased ability to repair DNA damage and defects in the apoptotic pathway (Gatti and Zunino 2005). Development of a new class of anticancer drugs that lack toxicity to healthy cells and are unaffected by common mechanisms of resistance would be a major advance in cancer chemotherapy. In this sense bioactive peptides, including cationic antimicrobial pep- tides (CAPs), are promising candidates for antitumor treatment.

CAPs have been found in all species that have been tested so far, including bacteria, fungi, plants and animals, and they probably represent one of the first evolved forms of defense of eukaryotic cells against pathogens (Zasloff 2002). An updated list of CAPs can be found in http://aps.unmc.edu/AP/main.php, with 1,393 entries. Most CAPs have a broad spectrum of antimicrobial activities; only 82 of the listed CAPs were active, however, against tumor cells.

Despite their diverse origins, antimicrobial peptides have common biophysical parameters, including small size, positive charge, and amphipathicity, that are likely important for peptide activity. These molecules are grouped according to structural characteristics, and are usually separated in three classes: (1) linear, often forming alpha-helical structures; (2) cysteine stabilized, beta-sheet structures; and (3) peptides with one or more predominant amino acid residues, but variable in structure (Yount et al. 2006). As stated before, not all CAPs are able to kill cancer cells, and to date, it has not been possible to predict an antitumor activity based on the peptide structure.

The short length and cationic/amphipathic properties of these molecules enable CAPs to interact and disrupt lipid membranes. Positively charged amino acid residues, such as lysine and arginine, and hydrophobic residues are frequently found in large numbers in CAPs (Hoskin and Ramamoorthy 2008). The high expression of anionic molecules, such as phosphatidylserine in the outer membrane leaflet of human tumor cells (Utsugi et al. 1991, Dobrzynska et al. 2005), as well as O-glycosylated mucins (Yoon et al. 1996) on cancer cell membranes, account for the net negative charge of these cells and their electrostatic interactions with cationic CAPs. In the case of magainin peptides, the cytotoxic activity for tumor cells was abolished by eliminating the electrical gradient across the plasma membrane. Apparently, the cellular potential is critical for peptide channel formation in tumor cell membranes and could determine the selective killing of tumor cells by CAPs (Cruciani et al. 1991). The interaction between CAPs and normal cells is not favored because of the overall neutral charge conferred by the zwitterionic 
major membrane components, such as sphingomyelin, phosphatidylethanolamine and phosphatidylcholine (Zachowski 1993).

CAPs interaction with cancer cell membranes is not mediated by receptors, since D-amino acid peptide analogues displayed an activity similar to the all-L-amino acid peptide (Rodrigues et al. 2008, Hetru et al. 2000).

Another mechanism for cancer cell killing by CAPs is the induction of apoptosis by permeation of mitochondrial membrane after internalization, release of cytochrome c, leadind to caspase 9 and 3 activation (Pardo et al. 2001). Both cationic and hydrophobic amino acids play a role in the peptide permeation of mitochondrial membranes (Horton et al. 2008). Alternatively, apoptosis may be induced by CAPs interaction with cell death receptors, such as Fas ligand, leading to caspase 8 activation. Interestingly, arginine, glycine and asparagine, integrin homing domain (RGD)-conjugated tachyplesin induced both pathways, suggesting that some CAPs may have more than one effect on cancer cells (Chen et al. 2001).

Protein glycosylation may alter the secondary structure of a membrane-associated protein or peptide, and altered glycosylation of membrane proteins is frequently found in malignant cells. Moreover, differential branching and sialic acid content of $\mathrm{N}$-linked glycans are associated with an increase in the net negative charge in the membrane of many cancer cells. Interestingly, peptide-glycosylation was associated with increased potency of drosocin in vitro (McManus et al. 1999). It is therefore likely that glycosylation of CAPs and/or cancer cell membrane proteins may influence the binding affinity of some CAPs for the cancer cell.

CAPs may be used in combination with conventional chemotherapeutic antitumor drugs in order to reduce effective doses, and thereby reduce harmful sideeffects frequently observed in treated patients. Cecropin A, in combination with 5-fluorouracil and cytarabine, showed a synergistic cytotoxic effect on human leukemia cells (Hui et al. 2002).

Representative naturally occurring CAPs with antitumor activities are depicted on Table I.

Peptides with antitumor activities have also been produced and/or identified from other sources, such as phage-, bacterial- and cell-display libraries. These pep- tides can exhibit direct tumor cell cytotoxicity, act as immunomodulators or as antiangiogenic factors. For a review on these peptides, see Daffre et al. (2008).

\section{A MODEL OF ANTITUMOR EFFECT OF A PEPTIDE}

Gomesin is a CAP isolated from hemocytes of the unchallenged Brazilian spider Acanthoscurria gomesia$n a$. It is a hairpin-like two-stranded antiparallel $\beta$-sheet structure formed by 18 amino acid residues and two posttranslational modifications, the $\mathrm{N}$-terminal pyroglutamic acid $(\mathrm{Z})$ and the $\mathrm{C}$-terminal amidated arginine residue (Silva et al. 2000, Mandard et al. 2002; Table I). A rigid conformation is maintained by two internal disulfide bridges formed by four cysteine residues, $\mathrm{Cys}^{2-15}$ and $\mathrm{Cys}^{6-11}$, together with six hydrogen bonds in the central part of the molecule, as well as at each end of the $\beta$-sheet (Mandard et al. 2002). The peptide is amphypathic, with a hydrophobic face (residues Leu ${ }^{5}, \mathrm{Tyr}^{7}$, $\mathrm{Val}^{12}$ and $\mathrm{Tyr}^{14}$ ) and three hydrophilic regions containing positively charged and polar amino acids at the Nterminus ( $\mathrm{Arg}^{3}$ and $\mathrm{Arg}^{4}$ ), at the C-terminus ( $\mathrm{Arg}^{16}$ and $\left.\operatorname{Arg}^{18}\right)$ and within the canonical $\beta$-turn $\left(\mathrm{Lys}^{8}, \mathrm{Gln}^{9}\right.$ and $\mathrm{Arg}^{10}$ ) (Fazio et al. 2006). A representation of gomesin is depicted on Figure 2.

As stated before, gomesin has a broad and strong microbicidal activity. The peptide is active against Grampositive and Gram-negative bacteria, filamentous fungi, yeast (Silva et al. 2000), Cryptococcus neoformans (Barbosa et al. 2007) and parasites, such as Plasmodium falciparum and Plasmodium berghei (Moreira et al. 2007).

The antitumor activity of gomesin was tested in vitro and in vivo (Rodrigues et al. 2008). Gomesin exerted direct cytotoxic effects on murine and human tumor cells in vitro. The estimated $\mathrm{IC}_{50}$ for the murine melanoma cell line B16F10-Nex2 was $3.58 \mu \mathrm{M}$, and was below $10 \mu \mathrm{M}$ for human tumor cell lines (Fig. 3). Human endothelial cells were also sensitive to gomesin in vitro, with an $\mathrm{IC}_{50}$ of $5.30 \mu \mathrm{M}$. The cytotoxic effect was time- and dose-dependent, and was not reversed after peptide removal. The $\beta$-hairpin structure and the amphipathicity of the peptide are important for antitumor activity, since substitution of cysteine residues by serine ones (eliminating one or both disulfide bridges), or disruption of the hydrophobic face (by substituting residues $\mathrm{Leu}^{5}$ and/or Val ${ }^{12}$ by serine units) reduced or abolished 
TABLE I

Naturally occurring CAPs with antitumor activity.

\begin{tabular}{|c|c|c|c|c|}
\hline Peptides & AA sequence* & Source & $\begin{array}{l}\text { Antitumor } \\
\text { Activity }\end{array}$ & Refs. \\
\hline \multicolumn{5}{|l|}{$\alpha$-helical } \\
\hline BMP27, BMP28 & $\begin{array}{l}\text { GRFKRFRKKFKKLFKKLSPVIPLLHL, } \\
\text { GGLRSLGRKILRAWKKYGPIIVPIIRI }\end{array}$ & $\begin{array}{l}\text { Bovine } \\
\text { Cathelicidin- } \\
\text { derived }\end{array}$ & In vitro & $\begin{array}{l}\text { Risso et al. } 1998, \\
\text { Risso et al. } 2002\end{array}$ \\
\hline $\begin{array}{l}\text { Cecropin A, } \\
\text { Cecropin B }\end{array}$ & $\begin{array}{l}\text { KWKLFKKIEKVGQNIRDGIIKAG- } \\
\text { PAVAVVGQATQIAKY } \\
\text { KWKVFKKIEKMGRNIRNGIVKAG- } \\
\text { PAIAVLGEAKAL }\end{array}$ & $\begin{array}{l}\text { Insects and } \\
\text { mammals }\end{array}$ & $\begin{array}{l}\text { In vitro, } \\
\text { Xenogeneic } \\
\text { model in vivo }\end{array}$ & $\begin{array}{l}\text { Moore et al. 1994, } \\
\text { Chan et al. 1998, } \\
\text { Winder et al. 1998, } \\
\text { Hui et al. 2002, } \\
\text { Ye et al. 2004, } \\
\text { Suttman et al. } 2008\end{array}$ \\
\hline LL-37/hCAP-18 & $\begin{array}{l}\text { LLGDFFRKSKEKIGKEFKRIVQRIK- } \\
\text { DFLRNLVPRTES }\end{array}$ & Human & In vitro & $\begin{array}{l}\text { Okumura et al. 2004, } \\
\text { Li et al. } 2006\end{array}$ \\
\hline $\begin{array}{l}\text { Magainins and } \\
\text { analogues }\end{array}$ & $\begin{array}{l}\text { GIGKFLHSAKKFGKAFVGEIMNS } \\
\text { (magainin 2) }\end{array}$ & Frog skin & $\begin{array}{l}\text { In vitro, } \\
\text { Xenogeneic } \\
\text { model in vivo } \\
\text { (local therapy) }\end{array}$ & $\begin{array}{l}\text { Cruciani et al. 1991, } \\
\text { Soballe et al. 1995, } \\
\text { Takeshima et al. 2003, } \\
\text { Cruz-Chamoro et al. 2006, } \\
\text { Lehman et al. } 2006\end{array}$ \\
\hline $\begin{array}{l}\text { Gaegurin 5, } \\
\text { Gaegurin } 6\end{array}$ & $\begin{array}{l}\text { FLGALFKVASKVLPSVKCAITKKC } \\
\text { FLPLLAGLAANFLPTIICFISYKC }\end{array}$ & Frog skin & In vitro & $\begin{array}{l}\text { Kim et al. } 2003 \text {, } \\
\text { Won et al. } 2006\end{array}$ \\
\hline Aurein 1.2 & GLFDIIKKIAESF & Frog skin & In vitro & Rozek et al. 2000 \\
\hline Citropin 1.1 & GLFDVIKKVASVIGGL & Frog skin & In vitro & Doyle et al. 2003 \\
\hline Melittin & GIGAVLKVLTTGLPALISWIKRKRQQ & Insect venom & $\begin{array}{l}\text { In vitro, In vivo } \\
\text { (melittin- } \\
\text { avidin } \\
\text { conjugate) }\end{array}$ & $\begin{array}{l}\text { Tosteson and Tosteson 1981, } \\
\text { Killion and Dunn 1986, } \\
\text { Saini et al. 1999, } \\
\text { Holle et al. } 2003\end{array}$ \\
\hline Epinicidin-1 & GFIFHIIKGLFHAGKMIHGLV & Fish & In vitro & Lin et al. 2009 \\
\hline Polybia-MP1 & I D W K K L L D A A K Q I L & Wasp venom & In vitro & Wang et al. 2008 \\
\hline \multicolumn{5}{|l|}{$\beta$-sheet } \\
\hline $\begin{array}{l}\text { Defensins } \\
\text { HNP-1 } \\
\text { HNP-2 } \\
\text { HNP-3 }\end{array}$ & $\begin{array}{l}\text { ACYCRIPACIAGERRYGTCIYQGRLWAFCC } \\
\text { CYCRIPACIAGERRYGTCIYQGRLWAFCC } \\
\text { DCYCRIPACIAGERRYGTCIYQGRLWAFCC }\end{array}$ & Human & $\begin{array}{l}\text { In vitro, In vivo } \\
\text { xenogeneic } \\
\text { model (HNP-1) }\end{array}$ & $\begin{array}{l}\text { Lichtenstein et al. } 1986 \text {, } \\
\text { Müller et al. 2002, } \\
\text { McKeown et al. 2006, } \\
\text { Xu et al. } 2008\end{array}$ \\
\hline $\begin{array}{l}\text { Bovine } \\
\text { Lactoferricin }\end{array}$ & FKCRRWQWRMKKLGAPSITCVRRAF & milk & $\begin{array}{l}\text { In vitro, In vivo } \\
\text { Xenogeneic } \\
\text { model, } \\
\text { antiangiogenic }\end{array}$ & $\begin{array}{l}\text { Yoo et al. 1997a, b, } \\
\text { Eliassen et al. 2002, } \\
\text { Mader et al. 2005, } \\
\text { Eliassen et al. } 2006\end{array}$ \\
\hline Tachyplesin I & KWCFRVCYRGICYRRCR & $\begin{array}{l}\text { Crustacean } \\
\text { hemocytes }\end{array}$ & $\begin{array}{l}\text { In vitro, } \\
\text { In vivo } \\
\text { (RGD- } \\
\text { tachyplesin) }\end{array}$ & $\begin{array}{l}\text { Li et al. 2000, } \\
\text { Chen et al. 2001, } \\
\text { Ouyang et al. 2002, } \\
\text { Chen et al. } 2005 \text {, } \\
\text { Shi et al. } 2006\end{array}$ \\
\hline Gomesin & ZCRRLCYKQRCVTYCRGR & Insect & $\begin{array}{l}\text { In vitro, In vivo } \\
\text { (local therapy) }\end{array}$ & Rodrigues et al. 2008 \\
\hline \multicolumn{5}{|l|}{$\begin{array}{l}\text { Linear, with } \\
\text { predominant AA }\end{array}$} \\
\hline $\begin{array}{l}\text { PR-39, Proline } \\
\text { arginine-rich } \\
\text { porcine } \\
\text { cathelicidin }\end{array}$ & $\begin{array}{l}\text { RRRPRPPYLPRPRPPPFFPPRLPPRIPP- } \\
\text { GFPPRFPPRFP }\end{array}$ & $\begin{array}{l}\text { Porcine } \\
\text { cathelicidin- } \\
\text { derived }\end{array}$ & In vitro & Ohtake et al. 1999 \\
\hline
\end{tabular}

*Amino acid (AA) sequences are given in one-letter code. Bold indicate Cys residues that form disulfide bonds. 


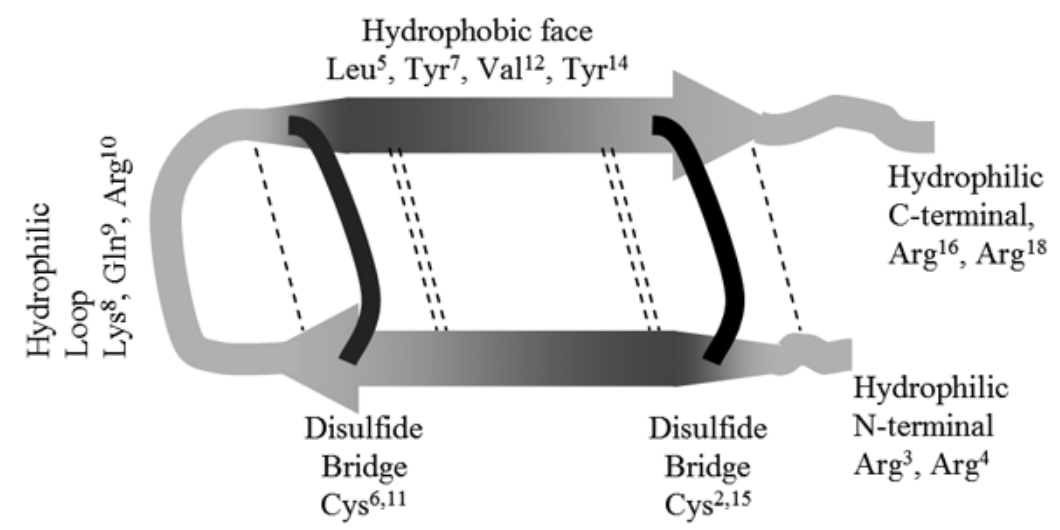

Fig. 2 - Schematic representation of gomesin. The molecule is formed by two antiparallel $\beta$-strands stabilized by $\underline{2}$ disulphide bridges (black lines) and $\underline{6}$ hydrogen bounds (hatched lines). Gomesin contains a hydrophobic face and three hydrophilic regions.

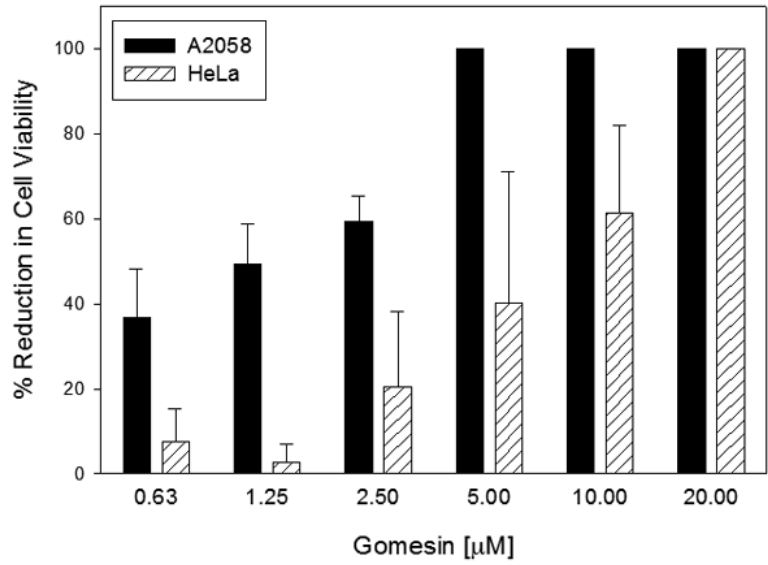

Fig. 3 - Gomesin cytotoxicity in vitro against human tumor cells. Human melanoma (A2058) and cervical cancer (HeLa) cells were treated in vitro with different concentrations of gomesin for 12 hours, and viable cells were counted in presence of Trypan Blue. The percentage of reduction of cell viability in relation to untreated cells is shown. The melanoma A2058 was the most sensitive and HeLa the most resistant cell line amongst all lineages studied (Rodrigues et al. 2008).

the cytotoxic effect. The enantiomer D-gomesin, synthesized employing D-amino acids and containing both disulfide bridges, was equally cytotoxic for tumor cells, suggesting that chiral recognition is not required for the antitumor effect (Rodrigues et al. 2008).

The peptide concentrates at the tumor cell membrane and forms clusters, suggesting the formation of pore structures. This putative pore formation by gomesin at the cell surface, and consequent cell permeabiliza- tion, caused (1) early morphological alterations, with increased granularity and loss of cytoplasmic content; (2) release of lactate dehydrogenase (LDH) in a dosedependent way; (3) partial inhibition of the respiration-dependent proton gradient; (4) internalization of immunoglobulins that reacted with tubulin filaments and with nuclear histone H1 (monoclonal A4M). The peptide did not induce apoptosis of tumor cells (Rodrigues et al. 2008).

Interestingly, the monoclonal antibody (mAb) A4M is an IgM that recognizes nuclear histone $\mathrm{H} 1$ in $\mathrm{B} 16 \mathrm{~F} 10$ Nex2 murine melanoma cells, but is not cytotoxic to the intact tumor cell (A.S. Dobroff et al., unpublished results). After treatment with low doses of gomesin, however, the mAb A4M was internalized in B16F10-Nex2 cells and showed additive cytotoxic activity in vitro. Therefore, gomesin at low concentrations could facilitate the penetration of drugs inside tumor cells, potentially reducing toxic doses and allowing penetration of molecules that are not directly cytotoxic to cells with intact membranes.

More importantly, topical in vivo treatment with gomesin significantly delayed subcutaneous murine melanoma development and significantly increased the survival of animals with tumors below the allowed maximal size limit. Male mice with established subcutaneous B16F10-Nex2 tumors $\left(4-10 \mathrm{~mm}^{3}\right)$ were treated topically three times a week with individual doses of $4 \mu \mathrm{g}$ of gomesin incorporated in $20 \mathrm{mg}$ of an anionic, 
oil-in-water cream. This effect can be explained by the direct effect of gomesin on tumor cells, but also by an effect on tumor neoangiogenesis, since endothelial cells were sensitive to low concentrations of the peptide. Repeated topical applications of gomesin did not affect the peripheral healthy skin of treated mice (Rodrigues et al. 2008).

Some patients may develop extensive, confluent regional metastases near the primary nodular melanoma. In these cases, surgical excision or radiotherapy are unsuitable, and topical treatment is a preferred alternative. Some topical treatments have indeed being used tentatively, but only partial responses were obtained with 5-aminolevulinic acid photodynamic therapy (Wolf et al. 1993), imiquimod (Steinmann et al. 2000, Hesling et al. 2004), dinitrochlorobenzene (Malek-Mansour 1973, Illig et al. 1984, von Nida and Quirk 2003), and diphencyprone (Damian and Thompson 2007). Gomesin could be an alternative for treatment of these patients and eventually also patients with other skin cancers.

\section{PERSPECTIVES}

Peptides used in protective protocols against pro- and eukaryotic cells, including fungi and tumor cells, can act directly on target cells or will elicit an immune response that may be effective to control infections and tumor development. Peptides allow structural changes to incorporate protective substitutions, chiral derivatives, non-natural amino acids and other modifications aiming at increased stability, efficiency and resistance to proteolysis. In this sense, they are much more drug-like than recombinant proteins. A great number of peptide sequences with biological activity is now recognized, and the finding that fragments of immunoglobulin variable chains have increased frequency of bioactivity opens a broad field of investigation. Peptide-based vaccines are now in development for various pathologies including cancer (Purcell et al. 2007). The possibility of chemical synthesis of a limitless variety of peptide sequences and derivatives poses the question of how many more reagents can be produced compared to our capacity to test them in different biological systems. The use of promiscuous peptides for vaccination of a genetically heterogeneous population is another aspect that has to be considered. Remarkably, the P10 from gp43 is a good vaccine candidate being presented by most Caucasian HLA-DR molecules, and being able to protect against massive $P$. brasiliensis infection in normal and immunosuppressed mice. The combination of chemotherapy and $\mathrm{P} 10$ vaccination is therefore a very promising strategy to treat human PCM. Antitumor peptides for systemic and topical treatment are additional tools that can be largely developed as adjuvants of conventional treatment.

\section{ACKNOWLEDGMENTS}

The authors thank Dr. Edna Haapalainen for the technical supervision with the electron microscopy. The present review was supported by grants from Fundação de Amparo à Pesquisa do Estado de São Paulo (FAPESP) and research fellowships from Conselho Nacional de Desenvolvimento Científico e Tecnológico (CNPq) and Coordenação de Aperfeiçoamento de Pessoal de Nível Superior (CAPES).

\section{RESUMO}

Peptídeos são moléculas particularmente reativas produzidas por uma grande variedade de espécies, aptos a exercer um número de funções em organismos uni- e multicelulares como mediadores, agonistas e substâncias regulatórias. Alguns deles exercem efeitos citotóxicos em células outras das que os produzem, e podem ter um papel controlando subpopulações e protegendo certas espécies ou tipos celulares. No presente, focalizamos peptídeos antifúngicos e antitumorais e discutimos alguns modelos nos quais seqüências específicas e estruturas exercem efeitos inibitórios diretos ou estimulam uma resposta imune protetora. O peptídeo letal ("killer"), deduzido de um anticorpo anti-idiotípico, com várias atividades antimicrobianas bem como outros peptídeos derivados de imunoglobulinas com atividades citotóxicas incluindo efeitos antitumorais são modelos estudados in vitro e in vivo. O peptídeo P10 da gp43 de $P$. brasiliensis e a perspectiva de vacina contra a paracoccidioidomicose é outro tópico ilustrando o efeito protetor in vivo contra um fungo patogênico. Peptídeos antimicrobianos catiônicos com atividades antitumorais são os principais revistos aqui. O tratamento local do melanoma murino com o peptídeo gomesina é outro modelo estudado na Unidade de Oncologia Experimental (UNONEX) da UNIFESP.

Palavras-chave: peptídeos bioativos, Paracoccidioides brasiliensis, células tumorais, peptídeo letal, melanoma, apoptose. 


\section{REFERENCES}

Aerts A, François IEJA, CAmmue BPA And ThevisSEN K. 2008. The mode of antifungal action of plant, insect and human defensins. Cell Mol Life Sci 65: 2069 2079.

Barbosa FM, Daffre S, Maldonado RA, Miranda A, Nimrichter L ANd Rodrigues ML. 2007. Gomesin, a peptide produced by the spider Acanthoscurria gomesiana, is a potent anticryptococcal agent that acts in synergism with fluconazole. FEMS Microbiol Lett 274: 279-286.

BECHINGER B. 1997. Structure and functions of channelforming peptides: magainins, cecropins, mellitin and alamethicin. J Membrane Biol 156: 197-211.

Bourgeois C, Bour JB, Aho LS ANd Pothier P. 1998. Prophylactic administration of a complementarity-determining region derived from a neutralizing monoclonal antibody is effective against respiratory syncytial virus infection in BALB/c mice. J Virol 72: 807-810.

BRAKHAGE AA. 2005. Systemic fungal infections caused by Aspergillus species: epidemiology, infection process and virulence determinants. Curr Drug Targets 6: 875-886.

Buissa-Filho R, Puccia R, Marques AF, Pinto FA, Muñoz JE, NosanchuK JD, TRAVAssos LR AND TABORDA CP. 2008. Monoclonal antibody against the major diagnostic antigen of Paracoccidioides brasiliensis mediates immune protection in infected Balb/c mice challenged intratracheally with the fungus. Infect Immun 76: 3321-3328.

Buzaid AC And AtKins M. 2001. Practical guidelines for the management of biochemotherapy-related toxicity in melanoma. Clin Cancer Res 7: 2611-2619.

Cenci E, Bistoni F, Mencacci A, Perito S, Magliani W, Conti S, Polonelli L and Vecchiarelli A. 2004. A synthetic peptide as a novel anticryptococcal agent. Cell Microbiol 6: 953-961.

Chan SC, Yau WL, Wang W, Smith DK, Sheu F-S AND CHEN HM. 1998. Microscopic observations of the different morphological changes caused by anti-bacterial peptides on Klebsiella pneumoniae and HL-60 leukemia cells. J Pept Sci 4: 413-425.

Chen J, Xu X-M, Underhill CB, Yang S, Wang L, Chen Y, Hong S, Creswell K and Zhang L. 2005. Tachyplesin activates the classic complement pathway to kill tumor cells. Cancer Res 65: 4614-4622.

Chen Y, Xu X-M, Hong S, Chen J, Liu N, Underhill CB, Creswell K ANd Zhang L. 2001. RGDtachyplesin inhibits tumor growth. Cancer Res 61: 2434-2438.
Cho Y, Turner J, Dihn N-G And Lehrer R. 1998. Activity of protegrins against yeast-phase Candida albicans. Infect Immun 66: 2486-2493.

Cisalpino PS, Puccia R, Yamauchi LM, Cano Mi, DA Silveira JF AND TRAVASsos LR. 1996. Cloning, characterization, and epitope expression of the major diagnostic antigen of Paracoccidioides brasiliensis. J Biol Chem 271: 4553-4560.

Cruciani RA, BARKer JL, ZaslofF M, Chen H-C AND Colamonici O. 1991. Antibiotic magainins exert cytolytic activity against transformed cell lines through channel formation. Proc Natl Acad Sci USA 88: 3792 3796.

Cruz-Chamoro L, Puertollano Ma, Puertollano E, Cienfuegos GA de And de Pablo MA. 2006. In vitro biological activities of magainin 1 alone or in combination with nisin. Peptides 27: 1201-1209.

Daffre S, Bulet P, Spisni A, Ehret-SAbatier L, RoDRIGUES EG AND TRavassos LR. 2008. Bioactive natural peptides. In: ATTA-UR-RAHMAN (Ed), Studies in Natural Product Chemistry, vol 35, Chapter 13; Elsevier, p. 597-691.

DAMIAN DL AND Thompson JF. 2007. Treatment of extensive cutaneous metastatic melanoma with topical diphencyprone. J Am Acad Dermatol 56: 869-871.

De Lucca A, Bland J, Jacks T, Grimm C and Walsh T. 1998. Fungicidal and binding properties of the natural peptides cecropin B and dermaseptin. Med Mycol 36: 291-298.

De Lucca A, Bland J, Vigo C, Jacks T, Peter J AND WALSH T. 2000. D-cecropin: proteolytic resistance, lethality for pathogenic fungi, and binding properties. Med Mycol 38: 301-308.

De LucCa AJ AND Walsh TJ. 2000. Antifungal peptides: Origin, activity, and therapeutic potential. Rev Iberoam Micol 17: 116-120.

De Lucca AJ, Jacks TJ, TAKemoto J, Vinyard B, Peter J, Navarro E And Walsh TJ. 1999. Fungal lethality, binding, and cytotoxicity of syringomycin E. Antimicrob Agents Chemother 43: 371-373.

Debono M And Gordee R. 1994. Antibiotics that inhibit fungal cell wall development. Annu Rev Microbiol 48: 471-497.

DENNING D. 1997. Echinocandins and pneumocandins - a new antifungal class with a novel mode of action. J Antimicrob Chemother 40: 611-614.

Diniz SN, Nomizo R, Cisalpino PS, Teixeira MM, Brown GD, Mantovani A, Gordon S, Reis LF AND DIAS AA. 2004. PTX3 function as an opsonin 
for the dectin-1-dependent internalization of zymosan by macrophages. J Leukoc Biol 75: 649-656.

Dobrzynska J, Szachowicz-Petelska B, SulkowsKY S AND FIGASZEWSKI Z. 2005. Changes in electric charge and phospholipids composition in juman colorectal cancer cells. Mol Cell Biochem 276: 113-119.

Doyle J, BRinkWORTH CS, WeGENER KL, CARVER JA, Llewellyn IN, Olver JH, Bowie PA AND WABNitz MJ. 2003. nNOS inhibition, antimicrobial and anticancer activity of the amphibian skin peptide citropin 1.1, and synthetic modificiations. The solution structure of a modified citropin 1.1. Eur J Biochem 270: 1141-1153.

Duda TFJR, Vanhoye D and Nicolas P. 2002. Roles of diversifying selection and coordinated evolution in the evolution of amphibian antimicrobial peptides. Mol Biol Evol 19: 858-864.

Eliassen LT, Berge G, SVEInbJornsson B, SVEndsen JS, VORLAND LH AND REKDAL O. 2002. Evidence for a direct antitumor mechanism of action of bovine lactoferricin. Anticancer Res 22: 2703-2710.

ELIASSEN LT ET AL. 2006. The antimicrobial peptide, Lactoferricin $\mathrm{B}$, is cytotoxic to neuroblastoma cells in vitro and inhibits xenograft growth in vivo. Int J Cancer 119: 493500.

Espinosa E, ZAMora P, FELIU J AND GonZALEZ BARON M. 2003. Classification of anticancer drugs - A new system based on therapeutic targets. Cancer Treat Rev 29: 515-523.

Fazio MA, Oliveira VX, Bulet P, Miranda MTM, DAFFre S AND MirAndA A. 2006. Structure-activity relationship studies of gomesin: importance of the disulfide bridges for conformation, bioactivities and serum stability. Biopolymers 84: 205-218.

François IE, AERTS AM, CAMmue BP AND THEVISSEN K. 2005. Currently used antimycotics: spectrum, mode of action and resistance occurrence. Curr Drug Targets 6: 895-907.

GATti L AND Zunino F. 2005. Overview of tumor cell chemoresistance mechanisms. Methods Mol Med 111: 127-148.

Hector R, Zimmer B And Pappagianis D. 1990. Evaluation of nikkomycins $\mathrm{X}$ and $\mathrm{Z}$ in murine models of coccidioidomycosis, histoplasmosis and blastomycosis. Antimicrob Agents Chemother 34: 587-593.

Helmerhorst EJ, Breeuwer P And Vanit Hof W. 1999. The cellular target of histatin 5 on Candida albicans is the energized mitochondria. J Biol Chem 274: 7286-7291.
HESLING C ET AL. 2004. In vivo and in situ modulation of the expression of genes involved in metastasis and angiogenesis in a patient treated with topical imiquimod for melanoma skin metastases. Br J Dermatol 150: 761-767.

Hetru C, Letellier L, Oren Z, Hoffman JA And Shai Y. 2000. Androctonin, a hydrophilic disulphide-bridged non-haemolytic anti-microbial peptide: a plausible mode of action. Biochem J 345: 653-664.

Holle L, Song W, Holle F, Wei Y, Wagner T And YU X. 2003. A matrix metalloproteinase 2 cleavable melittin/avidin conjugate specifically targets tumor cells in vitro and in vivo. Int J Oncol 22: 93-98.

Horton KL, Stewart KM, Fonseca SB, Guo Q And Kelley SO. 2008. Mitochondria-penetrating peptides. Chem Biol 15: 375-382.

Hoskin DW AND Ramamoorthy A. 2008. Studies on anticancer activities of antimicrobial peptides. Bioch Biophys Acta 1778: 357-375.

Hui L, Leung K And Chen HM. 2002. The combined effects of antibacterial peptide cecropin A and anti-cancer agents on leukemia cells. Anticancer Res 22: 2811-2816.

Illig L, PAul E AND BodeKer RH. 1984. Epifocal dinitrochlorobenzene herapyin malignant melanoma (experience during the last eight years). Anticancer Res 4: 293298.

IWAI LK ET AL. 2003. In silico prediction of peptides binding to multiple HLA-DR molecules accurately identifies immunodominant epitopes from gp43 of Paracoccidioides brasiliensis frequently recognized in primary peripheral blood mononuclear cell responses from sensitized individuals. Mol Med 9: 209-219.

IWAI LK ET AL. 2007. T-cell recognition of Paracoccidioides brasiliensis gp43-derived peptides in patients with paracoccidioidomycosis and healthy individuals. Clin Vaccine Immunol 14: 474-476.

JABLONOWSKI D AND SCHAFFRATH R. 2007. Zymocin, a composite chitinase and tRNase killer toxin from yeast. Biochem Soc Trans 35: 1533-1537.

JigGINS FM AND KIM K-W. 2005. The evolution of antifungal peptides in Drosophila. Genetics 171: 1847-1859.

KILliOn JJ AND DUNN JD. 1986. Differential cytolysis of murine spleen, bone marrow and leukemia cells by melittin reveals differences in membrane topography. Biochem Biophys Res Commun 139: 222-227.

Kim S, Kim SS, BANG Y-J, Kim S-J AND LEE B-J. 2003. In vitro activities of native and designed peptide antibiotics against drug sensitive and resistant tumor cell lines. Peptides 24: 945-953. 
Klassen R, Teichert S and Meinhardt F. 2004. Novel yeast killer toxins provoke S-phase arrest and DNA damage checkpoint activation. Mol Microbiol 53: 263-273.

KuRTz M AND Douglas C. 1997. Lipopeptide inhibitors of fungal glucan synthesis. Antimicrob Agents Chemother 35: 79-86.

LeE CH, Kim S, Hyun B, SuH JW, Yon C, Kim C, Lim Y AND KIM C. 1994. Cepacidine A, a novel antifungal antibiotic produced by Pseudomonas cepacia I. Taxonomy, production, isolation, and biological activity. J Antibiot 47: 1402-1405.

Lehman J, Retz M, Sidhu SS, Suttmann H, Sell M, Paulsen F, Harder J, Unteregger G And STÖCKLE M. 2006. Antitumor activity of the antimicrobial peptide magainin II against bladder cancer cell lines. Eur Urol 50: 141-147.

Lemaitre B, Reichhart J And Hoffman J. 1997. Drosophila host defense: differential induction of antimicrobial peptide genes after infection by various classes of microorganisms. Proc Natl Acad Sci USA 94: 14614-14619.

LeVi M, SÄllberg M, Rudén U, Herlyn D, MARUyama H, Wigzell H, Marks J AND Wahren B. 1993. A complementarity-determining region synthetic peptide acts as a miniantibody and neutralizes human-immunodeficiency-virus type-1 in vitro. Proc Nat Acad Sci USA 90: 4374-4378.

Li QF, OuYang GL, Li CY And Hong SG. 2000. Effects of tachyplesin on the morphology and ultrastructure of human gastric carcinoma cell line BGC-823. World J Gastroenterol 6: 676-680.

Li X, Li Y, Han H, Miller DW and Wang G. 2006. Solution structures of human LL-37 fragments and NMRbased identification of a minimal membrane-targeting antimicrobial and anticancer region. J Am Chem Soc 128: 5776-5785.

Lichtenstein A, Ganz T, Selsted ME And Lehrer RI. 1986. In vitro tumor cell cytolysis mediated by peptide defensins of human and rabbit granulocytes. Blood 68: 1407-1410.

Lim Y, Suh J-W, Kim S, Hyun B, Kim C and Lee C. 1994. Cepacidine A, a novel antifungal antibiotic produced by Pseudomonas cepacia. II. Physicochemical properties and structure elucidation. J Antibiot 47: 1406-1416.

Lin WJ, Chien YL, Pan CY, Lin TL, Chen JY, Chiu SJ AND Hui CF. 2009. Epinecidin-1, an antimicrobial peptide from fish (Epinephelus coioides) which has an antitumor effect like lytic peptides in human fibrosarcoma cells. Peptides 30: 283-290.
Litman GW, CANNON JP AND DishaW LJ. 2005. Reconstructing immune phylogeny: New perspectives. Nat Rev Immunol 5: 866-879.

Lobo DS, Pereira IB, Fragel-Madeira L, Medeiros LN, Cabral lm, Faria J, Bellio M, Campos RC, Linden R and Kurtenbach E. 2007. Antifungal Pisum sativum defensin 1 interacts with Neurospora crassa cyclin F related to the cell cycle. Biochemistry 46: 987-996.

Mader JS, SAlsman J, CONRAd DM ANd Hoskin DW. 2005. Bovine lactoferricin selectively induces apoptosis in human leukemia and carcinoma cell lines. Mol Cancer Ther 4: 612-624.

Magliani W, Conti S, Gerloni M, Bertolotti D and Polonelli L. 1997. Yeast killer systems. Clin Microbiol Rev 10: 369-400.

Magliani W, Conti S, Salati A, Arseni S, RavanetTI L, FrazZi R AND Polonelli L. 2004a. Engineered killer mimotopes: new synthetic peptides for antimicrobial therapy. Curr Med Chem 11: 1793-1800.

Magliani W, Conti S, Salati A, Vaccari S, RavaNetTi L, MAFFei DL AND Polonelli L. 2004b. Therapeutic potential of yeast killer toxin-like antibodies and mimotopes. FEMS Yeast Res 5: 11-18.

MALEK-MANSOUR S. 1973. Remission of melanoma with D.N.C.B. treatment. Lancet 2: 503-504.

Mandard N, Bulet P, Caille A, Daffre S AND VOVELLE F. 2002. The solution structure of gomesin, an antimicrobial cysteine-rich peptide from the spider. Eur J Biochem 269: 1190-1198.

Marques AF, DA Silva MB, Juliano MA, Travassos LR AND TABORDA CP. 2006. Peptide immunization as an adjuvant to chemotherapy in mice challenged intratracheally with virulent yeast cells of Paracoccidioides brasiliensis. Antimicrob Agents Chemother 50: 2814 2819.

Marques AF, da Silva MB, Juliano MA, Munhõz JE, Travassos LR And TABorda CP. 2008. Additive effect of P10 immunization and chemotherapy in anergic mice challenged intratracheally with virulent yeasts of Paracoccidioides brasiliensis. Microbes Infect 10: 1251-1258.

Marques da Silva SH, Queiroz-Telles F, Colombo AL, Blotta MH, Lopes JD ANd CAMARgo ZP. 2004. Monitoring gp43 antigenemia in paracoccidioidomycosis patients during therapy. J Clin Microbiol 42: 2419-2424.

Mattos Grosso D, De Almeida SR, Mariano M AND LOPES JD. 2003. Characterization of gp70 and anti-gp70 monoclonal antibodies in Paracoccidioides brasiliensis pathogenesis. Infect Immun 71: 6534-6542. 
Mavor AL, Thewes S And Hube B. 2005. Systemic fungal infections caused by Candida species: epidemiology, infection process and virulence attributes. Curr Drug Targets 6: 863-874.

McKeown STW, Lundy FT, Nelson J, Lockhart D, Irwin CR, Cowan CG AND Marley JJ. 2006. The cytotoxic effects of human neutrophil peptide-1 (HNP-1) and lactoferrin on oral squamous cell carcinoma (OSCC) in vitro. Oral Oncol 42: 685-690.

Mcmanus AM, Otvos L, Hoffman R And Craik DJ. 1999. Conformational studies by NMR of the antimicrobial peptide, drosocin, and its non-glycosylated derivatives: effects of glycosylation on solution conformation. Biochemistry 38: 705-714.

Moore AJ, Devine DA And Bibby MC. 1994. Preliminary experimental anticancer activity of cecropins. Pept Res 7: 265-269.

Mor A, Hani K And Nicolas P. 1994. The vertebrate peptide antibiotics dermaseptins have overlapping structural features but target specific organisms. J Biol Chem 269: 31635-31641.

Moreira CK, Rodrigues FG, Ghosh A, Varotti FD, Miranda A, DAfFre S, JACOBS-Lorena M AND MOREIRA LA. 2007. Effect of the antimicrobial peptide gomesin against different life stages of Plasmodium spp. Exp Parasitol 116: 346-353.

MÜller CA et AL. 2002. Human a-defensins HNPs-1, -2, and -3 in renal cell carcinoma. Influences on tumor cell proliferation. Am J Pathol 160: 1311-1324.

Nageic M, Nageic E, Baltisburger J, Well G, LesTER R AND DICKSON R. 1997. Sphingolipid synthesis as a target for antifungal drugs. J Biol Chem 272: 98079817.

Naumov GN, Towson JL, MacDonald IC, Wilson SM, Bramwell VH, GroOm AC AND CHMBERS AF. 2003. Ineffectiveness of doxorubicin treatment on solitary dormant mammary carcinoma cells or late-developing metastasis. Breast Cancer Res Treat 82: 199-206.

Nimrichter L, Rodrigues ML, Barreto-Bergter E AND TRAVAssos LR. 2008. Sophisticated functions for a single molecule: The role of glucosylceramides in fungal cells. Lipid Insights 2: 61-73.

OHTAKe T, FUJimoto Y, IKUTA K, SAito H, OHhira M, ONO M AND KoHgo Y. 1999. Proline-rich antimicrobial peptide, PR-39 gene transduction altered invasive activity and actin structure in human hepatocellular carcinoma cells. Br J Cancer 81: 393-403.

Okumura K, Itoh A, Isogai E, Hirose K, Hosokawa
Y, ABiko Y, ShibAta T, Hirata M AND Isogai H. 2004. C-terminal domain of human CAP18 antimicrobial peptide induces apotosis in oral squamous cell carcinoma SAS-H1 cells. Cancer Lett 212: 185-194.

Ouyang GL, Li QF, Peng XX, LiU QR AND Hong SG. 2002. Effects of tachyplesin on proliferation and differentiation of human hepatocellular carcinoma SMMC-7721 cells. World J Gastroenterol 8: 1053-1058.

Paluszynski JP, Klassen R and Meinhardt F. 2007. Pichia acaciae killer system: genetic analysis of toxin immunity. Appl Environ Microbiol 73: 4373-4378.

PARDO J ET AL. 2001. A role of the mitochondrial apoptosisinducing factor in granulysin-induced apoptosis. J Immunol 167: 1222-1229.

Pettoello-Mantovani M, Nocerino A, Polonelli L, Morace G, Conti S, Di Martino L, De Ritis G, IAfusco M ANd GuANDAlini S. 1995. Hansenula anomala killer toxin induces secretion and severe acute injury in the rat intestine. Gastroenterology 109: 19001906.

Pinto AR, Puccia R, Diniz SN, Franco MF AND TRAVASSOS LR. 2000. DNA-based vaccination against murine paracoccidioidomycosis using the gp43 gene from Paracoccidioides brasiliensis. Vaccine 18: 3050-3058.

Polonelli L, Conti S, Gerloni M, Magliani W, CasTAGnola M, Morace G and Chezzi C. 1991. 'Antibiobodies': antibiotic-like anti-idiotypic antibodies. J Med Vet Mycol 29: 235-242.

Polonelli L, Magliani W, Conti S, Bracci L, Lozzi L, Neri P, Adriani D, DE Bernardis F AND CASSONE A. 2003. Therapeutic activity of an engineered synthetic killer antiidiotypic antibody fragment against experimental mucosal and systemic candidiasis. Infect Immun 71: 6205-6212.

Polonelli L ET AL. 2008. Antibody complementaritydetermining regions (CDRs) can display differential antimicrobial, antiviral and antitumor activities. PLoS One 3(6): e2371. doi: 10.1371/journal.pone.0002371.

Puccia R, Schenkman S, Gorin PA and Travassos LR. 1986. Exocellular components of Paracoccidioides brasiliensis: identification of a specific antigen. Infect Immun 53: 199-206.

Purcell AW, McCluskey J And Rossjohn J. 2007. More than one reason to rethink the use of peptides in vaccine design. Nat Rev Drug Discov 6: 404-414.

Risso A, Zanetti M and Gennaro R. 1998. Cytotoxicity and apoptosis mediated by two peptides of innate immunity. Cell Immunol 189: 107-115. 
Risso A, Braidot E, Sordano MC, Vianello A, Macri F, Skerlavaj B, Zanetti M, Gennaro R AND BERNARDI P. 2002. BMAP-28, an antibiotic peptide of innate immunity, induces cell death through opening of the mitochondrial permeability transition pore. Moll Cell Biol 22: 1926-1935.

Roberts W And Selitrennikoff C. 1991. Zeamatin, an antifungal protein made from maize with membranepermeabilizing activity. J Gen Microbiol 40: 1771-1778.

Rodrigues EG AND TRAVASSOS LR. 1994. Nature of the reactive epitopes in Paracoccidioides brasiliensis polysaccharide antigen. J Med Vet Mycol 32: 77-81.

RODRIGUES EG ET AL. 2008. Effective topical treatment of subcutaneous murine B16F10-Nex2 melanoma by the antimicrobial peptide gomesin. Neoplasia 10: 61-68.

Rodrigues ML, Travassos LR, Miranda KR, Franzen AJ, Rozental S, De Souza W, Alviano CS AND BARreto-Bergter E. 2000. Human antibodies against a purified glucosylceramide from Cryptococcus neoformans inhibit cell budding and fungal growth. Infect Immun 68: 7049-7060.

Rozek T, Wegener KL, Bowie JH, Olver IN, CARVER JA, Wallace JC AND Tyler MJ. 2000. The antibiotic and anticancer active aurein peptides from the Australian Bell Frogs Litoria aurea and Litoria raniformis. The solution structure of aurein 1.2. Eur J Biochem 267: 53305341.

Saini SS, Chopra AK And Peterson JW. 1999. Melittin activates endogenous phospholipase D during cytolysis of human monocytic leukemia cells. Toxicon 37: 16051619.

SANTOS A AND MARQUINA D. 2004. Ion channel activity by Pichia membranifaciens killer toxin. Yeast 21: 151-162.

SCHMitT MJ AND BREINIG F. 2006. Yeast viral killer toxins: lethality and self-protection. Nat Rev Microbiol 4: 212-221.

SCHMitT MJ AND REITER J. 2008. Viral induced yeast apoptosis. Biochim Biophys Acta 1783: 1413-1417.

SHAI Y. 1995. Molecular recognition between membranespanning polypeptides. TIBS 20: 460-464.

SHI SL, WANG YY, Liang Y AND Li QF. 2006. Effects of tachyplesin and n-sodium butyrate on proliferation and gene expression of human gastric adenocarcinoma cell line BGC-823. World J Gastroenterol 12: 1694-1698.

Silva PI, DAFFre S AND Bulet P. 2000. Isolation and characterization of gomesin, a 18-residue cysteine-rich defense peptide from the spider Acanthoscurria gomesiana hemocytes with sequence similarities to horseshoe crab antimicrobial peptides of the tachyplesin family. J Biol Chem 275: 33464-33470.
Silva SH, Mattos Grosso D, Lopes JD, Colombo AL, Blotta MH, Queiroz-Telles F ANd CAmargo ZP. 2004. Detection of Paracoccidioides brasiliensis gp70 circulating antigen and follow-up of patients undergoing antimycotic therapy. J Clin Microbiol 42: 4480-4486.

Soballe PW, Maloy WL, Myrgra ML, JACOB LS AND HERLYN M. 1995. Experimental local therapy with lytic magainin peptides. Int J Cancer 60: 280-284.

Sorensen K, Kim K-H AND TAKEMOTO JY. 1996. In vitro antifungal and fungicidal activities and erythrocyte toxicities of Pseudomonas syringae pv. syringae. Antimicrob Agents Chemother 40: 2710-2713.

Steinmann A, Funk JO, Schuler G And VON DEN DRIESCH P. 2000. Topical imiquimod treatment of a cutaneous melanoma metastasis. J Am Acad Dermatol 43: 555-556.

Suttmann H, Retz M, Paulsen F, Harder J, Zwergel U, Kamradt J, Wullich B, UnteregGer G, StÖCKle M And Lehmann J. 2008. Antimicrobial peptides of the Cecropin-family show potent antitumor activity against bladder cancer cells. BMC Urol 8: 5.

TABorda CP, Juliano MA, PuCCIA R, Franco M AND Travassos LR. 1998. Mapping of the T-cell epitope in the major 43-kilodalton glycoprotein of Paracoccidioides brasiliensis which induces a Th-1 response protective against fungal infection in $\mathrm{BALB} / \mathrm{c}$ mice. Infect Immun 66: 786-793.

Taborda CP, Nakaie CR, Cilli EM, Rodrigues EG, Silva LS, Franco MF AND Travassos LR. 2006. Synthesis and immunological activity of a branched peptide carrying the T-cell epitope of gp43, the major exocellular antigen of Paracoccidioides brasiliensis. Scand J Immunol 59: 58-65.

TAKESAKO K, Kuroda H, InOUE T, HARUnA F, YoshiKAWA Y AND KATO I. 1993. Biological properties of aureobasidin A, a cyclic depsipeptide antifungal antibiotic. J Antibiot 46: 1414-1420.

TAKeshima K, Chikushi A, LeE K-K, Yonehara S AND MATSUZAKI K. 2003. Translocation of analogues of the antimicrobial peptides magainin and buforin across human cell membranes. J Biol Chem 278: 1310-1315.

Tavares PM, Thevissen K, Cammue BP, François IE, Barreto-Bergter E, TABorda CP, Marques AF, Rodrigues ML AND NimRichter L. 2008. In vitro activity of the antifungal plant defensin RsAFP2 against Candida isolates and its in vivo efficacy in prophylactic murine models of candidiasis. Antimicrob Agents Chemother 52: 4522-4525. 
TheVissen K, WARnecke DC, François IE, Leipelt M, Heinz E, Ott C, Zahringer U, Thomma BP, FERKET KK AND CAMmue BP. 2004. Defensins from insects and plants interact with fungal glucosylceramides. J Biol Chem 279: 3900-3905.

Tosteson MT And Tosteson DC. 1981. The sting melittin forms channels in lipid bilayers. Biophys J 36: 109116.

Travassos LR, Silva LS, Rodrigues EG, Conti S, Salati A, Magliani W And Polonelli L. 2004a. Therapeutic activity of a killer peptide against experimental paracoccidioidomycosis. J Antimicrob Chemother 54: 956-958.

Travassos LR, Taborda CP, Iwai LK, Cunha-Neto E AND PUCCIA R. 2004b. The gp43 from Paracoccidioides brasiliensis: A major diagnostic antigen and vaccine candidate. In: Domer JE, KobAYASHI GS (Eds), The Mycota XII, Human Fungal Pathogens, Springer-Verlag, Berlin-Heildeberg, p. 279-296.

TRAVASSOS LR, RODRIGUES EG, IWAI LK AND TABORDA CP. 2008a. Attempts at a peptide vaccine against paracoccidioidomycosis, adjuvant to chemotherapy. Mycopathologia 165: 341-352.

Travassos LR, TABorda CP AND COLOMBo AL. 2008b. Treatment options for paracoccidioidomycosis and new strategies investigated. Expert Rev Anti Infect Ther 6: 251-262.

Utsugi T, Schroit AJ, Connor J, Buccana CD AND FIDLER IJ. 1991. Elevated expression of phosphatidylserine in the outer leaflet of human tumor cells and recognition by activated human blood monocytes. Cancer Res 51: 3062-3066.

VON NIDA J AND QUIRK C. 2003. Successful treatment of in-transit melanoma metastases using topical 2-4 dinitrochlorobenzene. Australas J Dermatol 44: 277-280.

XU N ET AL. 2008. Human alpha-defensin-1 inhibits growth of human lung adenocarcinoma xenograft in nude mice. Mol Cancer Ther 7: 1588-1597.

WANG KR, ZHANG BZ, ZHANG W, YAN JX, Li J AND WANG R. 2008. Antitumor effects, cell selectivity and structure-activity relationship of a novel antimicrobial peptide polybia-MPI. Peptides 29: 963-968.

Winder D, GunzburG WH, ERfle V And SAlmons B. 1998. Expression of antimicrobial peptides has an antitumor effect in human cells. Biochem Biophys Res Comm 242: 608-612.
Wolf P, Rieger E AND KerL H. 1993. Topical photodynamic therapy with endogenous porphyrins after application of 5-aminolevulinic acid. An alternative treatment modality for solar keratoses, superficial squamous cell carcinomas, and basal cell carcinomas? J Am Acad Dermatol 28: 17-21.

Won H-S, Seo M-D, Jung S-J, LeE S-J, KAng S-J, Son W-S, Kim H-J, PARK T-K, PARK S-J AND LeE B-J. 2006. Structural determinants for the membrane interaction of novel bioactive undecapeptides derived from gaegurin 5. J Med Chem 49: 4886-4895.

Ye J-S, Zheng J-X, Leung KW, Chen HM And Sheu F-S. 2004. Induction of transient ion channel-like pores in a cancer cell by antibiotic peptide. J Biochem 136: 255-259.

Yoo Y-C, Watanabe R, Koike Y, Mitobe M, ShimaZAKi K, Watanabe S And AzUma I. 1997a. Apoptosis in human leukemic cells induced by lactoferricin, a bovine milk-derived peptide: involvement of reactive oxygen species. Biochem Biophys Res Commun 237: 624-628.

Yoo Y-C, Watanabe R, Watanabe K, Hata K, ShiMAZAKI K AND AZUMA I. 1997b. Bovine lactoferrin and lactoferricin, a peptide derived from bovine lactoferrin, inhibit tumor metastasis in mice. Jpn J Cancer Res 88: $184-190$.

Yoon WH, PARK HD, Lim K AND HWANG BD. 1996. Effect of O-glycosylated mucin on invasion and metastasis of HM7 human colon cancer cells. Biochem Biophys. Res Commun 222: 694-699.

Yount NY, Bayer AS, Xiong YQ ANd YeAman MR. 2006. Advances in antimicrobial peptide immunobiology. Biopolymers 84: 435-458.

ZACHOWSKI A. 1993. Phospholipids in animal eukaryotic membranes: transverse asymmetry and movement. Biochem J 294: 1-14.

ZASLOFF M. 1987. Magainins, a class of antimicrobial peptides from Xenopus skin: isolation, characterization of two active forms and partial cDNA sequence of a precursor. Proc Natl Acad Sci USA 84: 5449-5453.

ZASLOFF M. 2002. Antimicrobial peptides of multicellular organisms. Nature 415: 389-395. 